\title{
Recent progress in Competitive Intelligence, Competitive Technical Intelligence and Knowledge Management ${ }^{1}$
}

Dou Henri*

\begin{abstract}
This paper discusses the role of competitive intelligence and knowledge management to create, maintain and sustain competitive advantages. The triple helix model, based on the integration of the public sector (government), business models (private corporations) and universities to promote innovation is examined. Research trends in competitive intelligence are presented. It concludes that the systematic use of the technology monitoring should support the comparison between various business models of companies that hold the market best practices and form a basis to knowledge for the decision making process and strategies development.
\end{abstract}

Key-Words: Competitive Intelligence, Triple Helix model, Innovation, Competitive advantage.

\section{Resumo}

Trata do desenvolvimento recente da inteligência competitiva e da gestão do conhecimento como abordagens essenciais para a criação, manutenção e sustentação de vantagens competitivas. Examina o modelo da tríplice hélice baseado na integração de forças entre o setor público (governo), modelos de negócio (organizações privadas) e universidades, voltado para a promoção da inovação. Apresenta uma série de tendências na pesquisa em inteligência competitiva. Conclui que do uso sistemático de ferramentas de monitoramento tecnológico, deve apoiar a comparação entre diversos modelos de negócios das empresas que detém as melhores práticas de atuação no mercado, além de formar uma base de conhecimento para o processo decisório e desenvolvimento de estratégias competitivas.

Palavras-chave: Inteligência competitiva, Modelo da tríplice hélice, Inovação, Vantagem competitiva.

\section{Resumen}

Trata del reciente desarrollo de la inteligencia competitiva y la gestión del conocimiento como criterios esenciales para la creación, el mantenimiento y sustento de ventajas

\footnotetext{
${ }^{1}$ Symposium on Information Science - UNB National University of Brasilia - September 1-2, 2008, Brasilia

*ESCEM, 1 rue Léo Delibes, BP 0535, 37205 Cedex 3, France douhenri@ yahoo.fr 
competitivas. Examina el modelo de triple hélice sobre la base de la integración de las fuerzas entre el sector público (gobierno), los modelos de negocio (entidades privadas) y las universidades, dirigidos a la promoción de la innovación. Presenta una serie de tendencias en la investigación en inteligencia competitiva. Llega a la conclusión de que el uso sistemático de herramientas para el seguimiento de la tecnología debe apoyar la comparación de diferentes modelos de negocios de las empresas que tiene las mejores prácticas de rendimiento en el mercado además de formar una base de conocimientos para la toma de decisiones y el desarrollo de estrategias competitivas.

Palabras-clave: Inteligencia competitiva, el modelo de triple hélice, la innovación, ventaja competitiva.

\section{Introdução}

The worldwide development of the competition between states, firms, research laboratories, universities, regions, generalized all the methods and tools able to maintain or to develop the competitive advantages of the former entities ${ }^{2} 1$. In this paper we will not examine the aspect linked to the geopolitics and engagement of the national institution to level the ground to export of their national firms, like in the USA for example ${ }^{3}$. We will remain on the ground of research and trends in the discipline mentioned above in the title of this presentation $^{4}$.

Before beginning to underline some trends in these activities, it is necessary to have in mind some global moves made recently by various states and which will impact the research made in Competitive Intelligence and Technical Intelligence and Knowledge Management ${ }^{5}$.

\section{The Triple Helix and the new public and private partnerships}

One point which is very important today is that we are in the so called "research economy driven". To illustrate this matter let us take for example the work produced by the

\footnotetext{
${ }^{2}$ R. Florida: The flight of the creative class, Harper Collins, 2005

${ }^{3}$ Mission of the Advocacy Center: Our mission is to coordinate U.S. Government resources and authority in order to level the playing field on behalf of U.S. business interests as they compete against foreign firms for specific international contracts or other U.S. export opportunities. In doing so, the Advocacy Center helps create and retain U.S. jobs through exports. Retrieved from the world wide Web, August 17th 2008: http://www.export.gov/advocacy/

${ }^{4}$ Part of this paper will be presented at the International Forum on Technical Innovation and Competitive Technical Intelligence, Beijing October 16 $6_{\mathrm{th}}-18_{\mathrm{th}}$ for more information see http://www.ciworldwide.org

5 Méthode de diagnostic du système d'innovation dans les regions françaises, Jean Claude Prager, Ministère de l'Economie de l'emploi et de l'industrie, available from the Worl Wide Web August 28th 2008: http://www.innovationlejournal.com/spip.php?article3169
} 
InterregIII ${ }^{6}$ in the field of the Triple Helix ${ }^{7} 6$. The example below illustrates what we mean by triple helix ${ }^{8}$. The development of the best conditions to create knowledge and competencies are reached at the intersection of the Governmental institution - research centers - industry. This called for a new type of partnership between the public and private institutions. The figure 1 illustrate this matter.

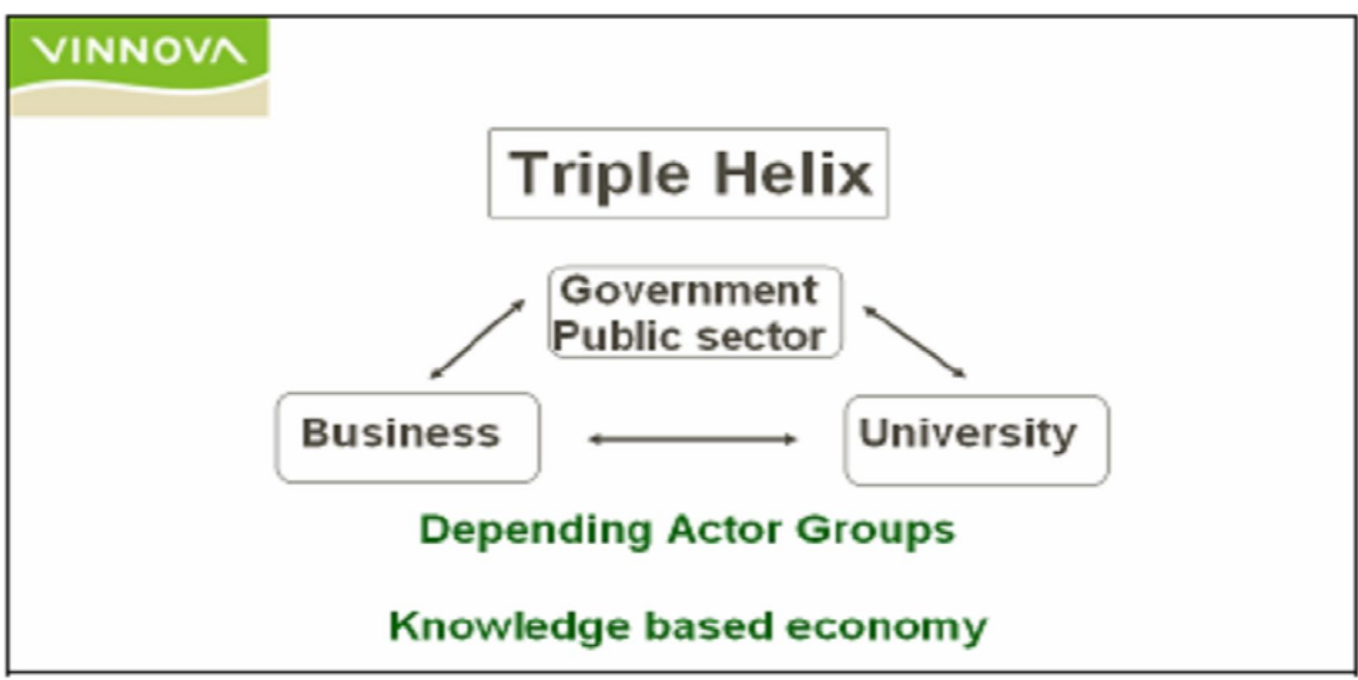

Figure 1 - Illustration of the public and private partnership

\section{Innovation}

Innovation is a word which is used in many ways. It is important to give to this word the right signification before continuing this presentation. Many reports have been published those last years to emphasize the role of innovation in the development of the state's economy. The well know Palmisano ${ }^{9}$ report from the USA brushes the context in which innovation must

\footnotetext{
${ }^{6}$ Interreg III is a European Community research program program the aim of the program is te following: INTERREG III is a EC Community Initiative to promote transnational co-operation on spatial planning by encouraging harmonious and balanced development of the European territory. The overall aim is to ensure that national borders are not a barrier to balanced development and the integration of Europe and to strengthen cooperation of areas to their mutual advantage. The Initiative runs from 2000 to the end of 2006. Retrieved from the Worl Wide Web August 17th 2008 : http://www.interregiii.org.uk/

${ }^{7}$ The Triple Helix as a Model for Innovation Studies -(Conference Report), Science \& Public Policy Vol. 25(3) (1998) 195-203 Loet Leydesdorff \& Henry Etzkowitz see also Industry \& Higher Education 12 (1998, nr. 4) 197-258, http://users.fmg.uva.nl/lleydesdorff/th2/ihe98.htm see also L. Leydesdorff et H. Etzkowitz, « Triple helix of innovation : introduction », Science and Public Policy, 1998

${ }^{8}$ Centro Formativo Privinciale, Guiseppe Zanardelli, Azienda speciale de la provincia de Brescia, Interreg III C Brics-workshop - Aalborg 13th Feb 2006 Dr Per Eriksson, - Director General VINNOVA - Swedish Governmental Agency for Innovation Systems.

${ }^{9}$ Analysis of the Palmisano Report by Tamada Shumpeter a fellow of the RIETI (Japan) http://www.rieti.go.jp/en/columns/a01_0158.html
} 
be developed. Again, we will take the meaning of innovation from the work of the InterregIII program.

Step 1: Generally most of the people (and mainly in research and specially in France) believe that the Government should subsidize the research and the education as a finality. Then knowledge will be created. This is common place and many people stick to this view without thinking how the money necessary for the research and the development will be found.

Step 2: Now if we consider the success stories of the Silicon Valley or Triangle park in the US and if we look to the mechanism which bring the success of these clusters, it is clear that the step 1 should be completed by another step which is fundamental, this is the INNOVATION step:

It is necessary to transform the knowledge which has been created in step 1 to money.

The better example of this process is indicated in the statement presented by Elias Zerhouni $^{10}$, Director of the National Institutes of Health (NIH) in the USA: "The success of American scientific research depends on the existing implicit partnership between academic research, the government and industry. The research institutions have the responsibility to develop the scientific capital. The Government finances the best teams by a transparent system of selection. Industry holds the critical role to develop robust products intended for the public. This strategy is the key of American competitiveness and must be maintained."

Do not forget also, that innovation is also a matter of spirit, of the will of the decision makers to move into an uncertain world. This means that the "culture" of the company of the people in charge of the governmental institutions, of the research centers of the universities are concerned ${ }^{11}$.

As we will see below, this definition of innovation is to take all the knowledge and competences created in step one to transform them in MONEY, will impact the research in the field of intellectual property, not only to protect the knowledge of a firm or a research institution, but also to know what is the development of the products and applications of

http://www.amazon.fr/Competitive-Advantage-Nations-New-Introduction/dp/0684841479 published in 1998. Extract: Why do some Nations succeed and other fall in international competition? This question is perhaps the most asked economic question of our time. Competitiveness has become one of the central preoccupations of government and industry of every Nation. The United States is an obvious example, with the growing public debate about the apparently greater economic success of other trading Nations. But intense debate about competitiveness is also taking place today in such "success story" nations as Japan and South Korea.

${ }^{10}$ Presented in December 2006 during the congress organized by the American Society of Hematology. Cited in What model the French public research, Les Echos, wednesday January 10th 2007, Alain Perez.

${ }^{11}$ Schumpeter 1911 farsighted visions on economic development, Thornjorn Knudsen and Markus C. Becker, American Journal of Economics and Sociology, April 2002. 
different inventions in various fields. This will also means that a bridge should be created between fundamental research (the term does not fit very well here, since in our opinion the difference between fundamental research and applied research is becoming smaller and smaller). This means also that all progress not in your country but in the whole world must be analyzed, commented, weighted and integrated in the development strategy of the state.

\section{Clusters and poles of competitiveness}

The work of Michael Porter ${ }^{12}$ show years ago, that the clusters are the best place to develop innovation and to create the most suitable Private and Public Partnership. This recommendation has been followed by various countries. We will present here the case of the poles of competitiveness in France. After the development of a national program in Economic Intelligence a call for project was issued from the Ministry of Industry. The objective was to gather in a pole of competitiveness the stakeholders of an area of production and research concerned by the economy development of the region. More than 55 poles of competitiveness were selected. Some of them have an international status, other have only a national one. The considerations for the selection of a pole, is linked to a certain number of items which are well described in a report issue from the European Community ${ }^{13} 12$. Another important point is that most of the poles are focused on export and they use the so called French Strategic Technologies. It is then clear that one of the goal of the poles is to make the best conditions to develop Public and Private Partnership and to facilitate the work in laboratories and research centres, it should be very suitable that the national program of "Economic Intelligence" includes a part devoted to the role of patents ${ }^{14}$ in the development of innovation, knowledge of the technologies and their applications as well as the protection of the national knowledge and know-how. Various experiments developed in this direction by the CIWORLDWIDE ${ }^{15}$

\footnotetext{
${ }^{12}$ Michael Porter, The Competitive advantages of Nations.

${ }^{13}$ Strategic Intelligence and Innovative Clusters - A Regional Policy Blueprint Highlighting the use of Strategic Intelligence in Cluster policy. Interreg III C (European Community)

${ }^{14}$ Patent Analysis for Competitive Technical Intelligence and Innovative Thinking H Dou, V Leveillé, S

Manullang \& JM Dou Jr Data Science Journal, Vol. 4 (2005) pp.209-236

See also

The use of structured online information in technology forecasting in third world countries Agus Salim Ridwan, Kadasah Suryadi, Dou H Congrés International de Génie Industriel, Montreal, 25 $\square 28$ Mai 1999

See also

Benchmarking R\&D and companies through patent analysis using free databases and special software: a tool to improve innovative thinking

Henri Dou

World Patent Information, Volume 26, Issue 4 , December 2004, Pages 297 $\square 309$

${ }^{15} \mathrm{http}$ ://www.ciworldwide.org
} 
organization in Chile, Thailand, Indonesia, Spain... underline the benefit of this approach. The development of the poles of Competitiveness will require various types of research, from sociology and psychology to organization and management through the analysis of the right information: this called the governance of the pole, that is to say the central body which will be in charge to apply and follow the progress of the road map of the pole determined by the stakeholders: governmental institutions, research laboratories and industry. In the same time a good coordination and collaboration of the stakeholders should be done, generally with the help of a platform to develop knowledge. and innovation. Because innovation as we saw before is the transformation of the knowledge and competences created by research institutions in money, the research laboratory should get a real R\&D culture.

It is very important to accelerate the transfer. To do it is not really difficult and the way in that direction has been show by the Japan in 1998. The development of the TLO ${ }^{16}$ and the policy of patents in national institutions show the way to follow. But the important point is not to wait 30 years to have the development of a cluster, but to do it in 10 years for instance.

\section{Information sources}

The development of the globalization and the arrival of the BRIC (Brazil, Russia, India, China) underline the impact of new information sources in sciences and technology. Most of the time, in the past the information access was developed and still is through an international set of scientific journals with a very large domination of the Anglo-Saxon countries and of course by the English as the publication language. The use for instance of the Scientific Citation Index as a mean to rank institutions and people via the bias of the citation of their papers induces a large distorsion since most of the time the national journals are not present in the list of journals used by the citation index. With the arrival of the might of different Asian countries and most certainly China, the information sources for the companies and institutions which want to maintain or create competitive advantages change dramatically. The amount of information available in Chinese and not published in English (the same is true for Japan and to a certain extend for Russia) is increasing dramatically and for instance

\footnotetext{
${ }^{16}$ http://www.jauiptm.jp/en/tlo/tlo.html

"A technology licensing organization (TLO) is a corporation, which obtains patents for university researchers' research results and licenses out those technologies to private companies, serving as an "intermediary" between industry and universities."
} 
Baidu ${ }^{17} 16$ (the equivalent of Google in China) which allows the query of the Chinese Web will become for the most important companies (and also for the organizations working in science and technology analysis for the Government) a necessity. This of course pin point the role of the language and of the automatic translators.

Let us take an example from two analysis dealing with the following subject: "hybrid wheat" determination of the key research place in China. One will be done from the western databases available through Dialog for example and the other by using only the Chinese Web. A more detailed study could be done through a Chinese database like Wafang ${ }^{18}$ for instance.

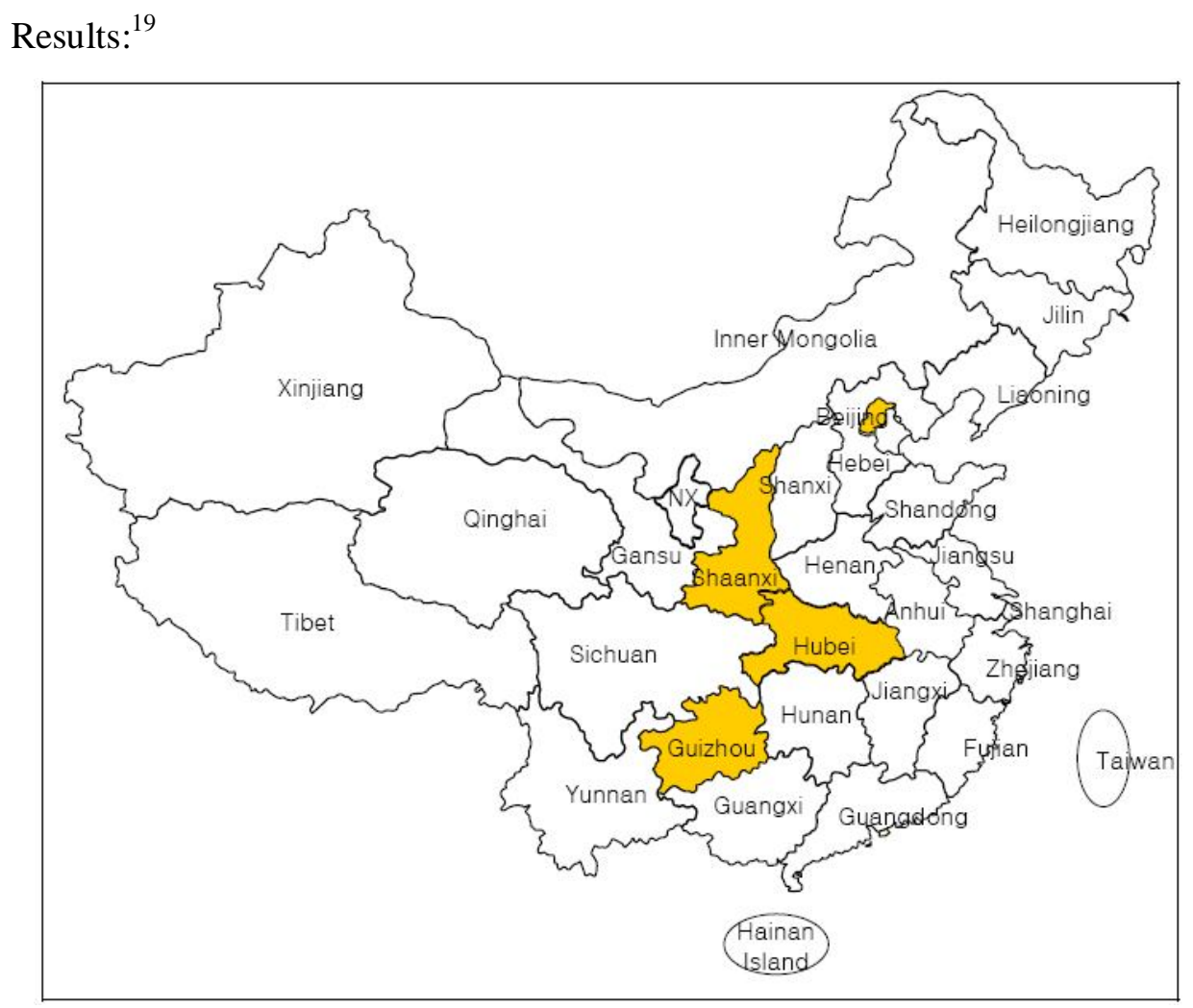

Figure 2 - Map of the Chinese research in « hybrid wheat » using the database Current Contents (2006)

\footnotetext{
${ }^{17}$ Baidu (Chinese: $\square \square$; pinyin: Băidù) (NASDAQ: BIDU) is the leading Chinese search engine for websites, audio files, and images. Baidu offers 57 search and community services including an online collaboratively-built encyclopedia (Baidu Baike), and a searchable keyword-based discussion forum.[1] As of March 21, 2008, Baidu is ranked 19th overall in Alexa's internet rankings.[2] In December 2007 Baidu became the first Chinese company to be included in the NASDAQ-100 index.[3]

Baidu provides an index of over 740 million web pages, 80 million images, and 10 million multimedia files.[4] The domain baidu.com attracted at least 5.5 million visitors annually by 2008 according to a Compete.com survey. (from Wikipedia http://en.wikipedia.org/wiki/Baidu )

${ }^{18}$ Retrieve from the World Wide Web, 16th June 2008 : http://www.wanfangdata.com.cn/

${ }^{19}$ Guenec Nadège and Dou Henri Présentation d'un portail chinoisde ressources bibliographiques.

Soumis au Bulletin de Documentation Belge
} 
The provinces in yellow are those concerned by the development of researches and applications dealing with the « hybrid wheat»

Searching the Chinese Web (of course it is necessary to read Chinese correctly !) with Baidu and looking for research institutions we obtain the following map presented in figure 3 . (2006).

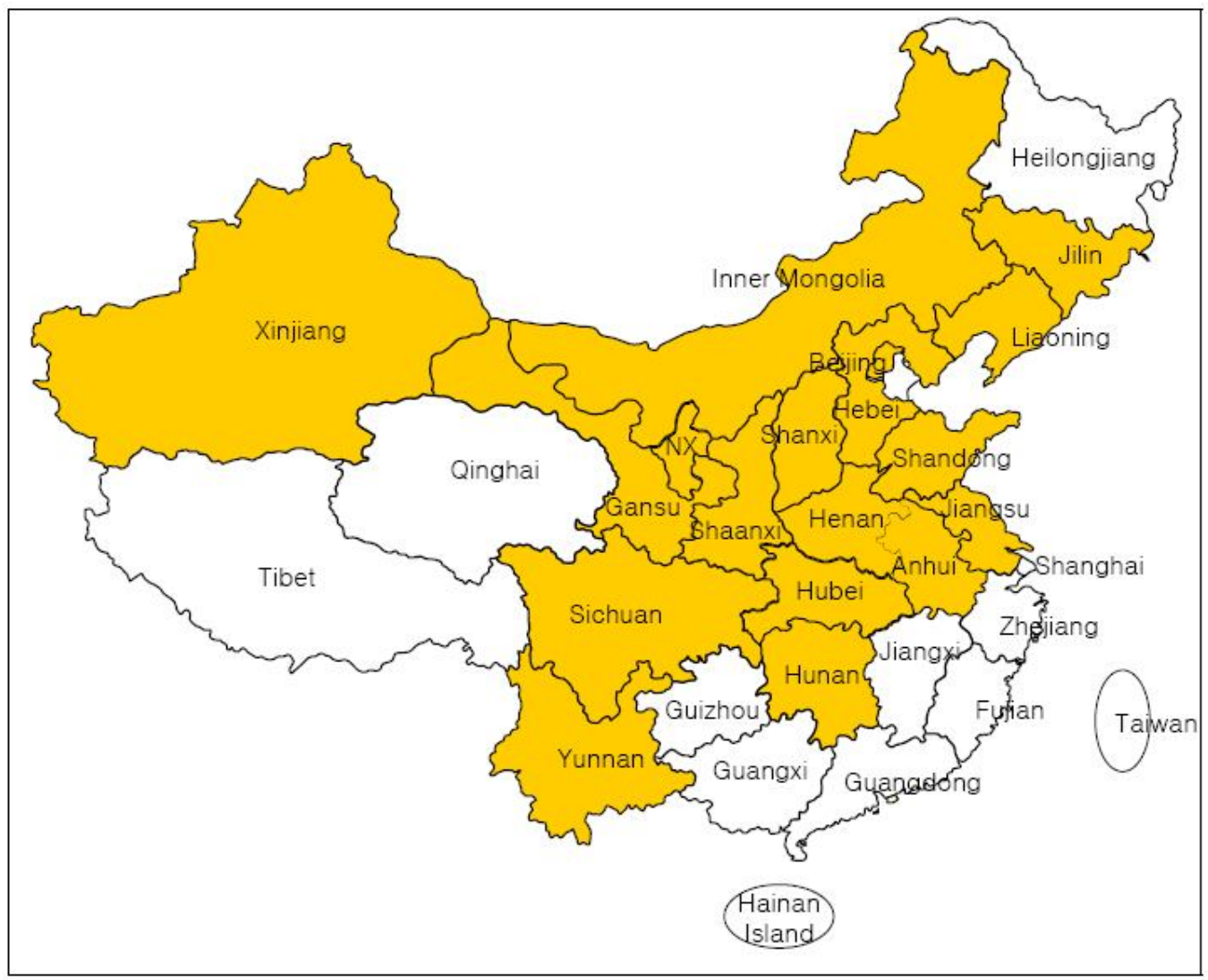

It is clear that the results are very different and this is not obvious at all that the best research results are published in key journals, since the Chinese language offers some protection against the foreigners' analysis. This short example underlines that a global strategy of critical information sources must be developed for the critical technologies by the main companies and research institutions. The Federal State, can of course creates a special bureau to investigate these information sources - because of the cost involved it is clear that this can only be done for the key area of the country development. It is necessary to avoid to be naïve because as in economy, the "rules of the game" in divulgation of the science and technology is changing. It is clear, for instance that in the paper published by Massari ${ }^{20}$ and al

\footnotetext{
${ }^{20}$ Marcio de Miranda Santos19, Gilda Massari Coelho, Dalci Maria dos Santos, Lélio Fellows Filho Text mining 
and dealing with the text mining on the subject nanotechnologies, the volume of papers published by countries in related nanotechnology areas may be considered as good for the westerns and may be South American countries, but could be handle with great care when the production of China is concerned.

\section{V - Trends in research in Competitive Intelligence and Competitive Technical Intelligence}

The subject is really vast and this paper will not be sufficient to move in all the areas of the former topics concerned. For the readers which read French the referential of education in Economic Intelligence which has been developed by the French Experts in that field can be a good tool to see all the areas which can be developed ${ }^{21}$. But, in this presentation we will point the areas which in our opinion are the most important so that the research which will be done will be really useful and will be well integrated in the development of the Clusters, companies and triple helix concept.

\section{A - The overload of information}

Today the institutions, the companies are facing an increasing load of information. This information is present in multi-formats, multi-supports and can be formatted or not. The sources are wide, from the commercial databases, to the internal information of the company, going through WEB2, RSS fluxes, Blogs etc.... If you add to that the increasing weight of the pictures, adds and videos, with a multilingual approach, you can see that the scene of information retrieval handling and analysis is more and more complicated.

The solutions choose today are relatively wide, but they are not global and most of the time they do not cover all the needs of the users. They are characterized by different names such as enterprise search (search engine dedicated to the enterprise), or ECM (Enterprise Content Management). An excellent article on ECM is published in Wikipedia ${ }^{22}$ which give the following definition:

as a valuable tool in foresight exercises:a study on nanotechnology, Technological Forecasting and Social Change Volume 73, Issue 8, October 2006, Pages 1013-1027

${ }^{21}$ Retrieved from the World Wide Web August 17th 2008:

http://www.intelligenceeconomique.gouv.fr/rubrique.php3?id_rubrique=33 allow to download a pdf document with all the various areas concerned by education and research

${ }^{22}$ Retrieved from the World Wide Web August 20th 2008:

http://en.wikipedia.org/wiki/Enterprise_content_management 
Enterprise content management (ECM) is a set of technologies used to capture, store, preserve and deliver content and documents and content related to organizational processes. ECM tools and strategies allow the management of an organization's unstructured information, wherever that information exists. In this area, all the researches made to index the information to improve its dissemination to make people able to comment it and to disseminate the comments are welcome. Some solutions are available as Open Source, other from various firms may be very expensive. Then research on storage and handling of pictures, videos, unstructured information will be welcome ${ }^{23}$. In the same time internal search engines dedicated to one firm will also be important as well as the coding of the strategic information.

\section{B - Datamining, text mining, bibliometrics}

This is one of the most well know area of research in this area two aspects may be considered: the structured ${ }^{24}$ (or formatted) information as available for instance from commercial hosts such as Dialog, PubMed, Questel Orbit ... these providers of commercial databases online have various structured formats which allow a fast bibliometrics treatment and the development of statistical analysis ${ }^{25}$ on various set of data. In this area the work of Bernard Doucet ${ }^{26}$, Alan Porter $^{27}$ and Henri Dou ${ }^{28}$ which gave rise to commercial applications are some of the best know in the domain. These applications allow from various set of formatted data to create new information (elaborated information) on the form of lists, network, matrices etc... the data are grouped according various parameters of statistical analysis. This gives a global view of the information contained in the set of data analyzed.

\footnotetext{
${ }^{23}$ Contemporary Issues of Enterprise Content Management The Case of Statoil Bjørn Erik Munkvold,Tero Päivärinta, Anne Kristine Hodne and Elin Stangeland Agder Scandinavian Journal of Information Systems, 2006, 18(2):69-100 paper available from the World Wide Web August 20th 2008 http://www.e-sjis.org/journal/volumes/volume18/no2/munkvoldetal-18-2.txt

${ }^{24}$ Structured data: references which have at the beginning of each reference field an univocal set of letters: TI for title, AU - for authors, etc... follow by the title the names of the authors with separators between names, etc...

${ }^{25}$ Bibliometry technique and software for patent intelligence mining (chapter) in Managing Strategic intelligence. Techniques and Technologies

Henri Dou and Jean-Marie Dou Jr

Editor Mark Xu, IGI Global, England ISBN 978-59904-243-5 15 May 2007

${ }^{26}$ IRIT (2006). The visualization of Tetralogie results. Retrieved July 7, 2006, from http://atlas.irit.fr/petitexemple.html

${ }^{27}$ VantagePoint (2006). Description of VantagePoint. Retrieved July 2, 2006, from www.gtresearchnews.gatech.edu/newsrelease/vantagepoint.htm

${ }^{28}$ The work developed during more than 15 years at the CRRM gave rise to several line of bibliometric products such as Dataview, Matrism. Other commercial products were developed by students from the CRRM in the Matheo $\square$ Software company. This give rise to the Matheo suite (Patent, Web, Analyzer)
} 
Today, these approaches are well mastered and the only problems are the structuring of the information. This could then extend the use of such software to other information sources (Web, press agency wire, etc...). This is this area called sometimes "reformatting" which should call the attention of the researcher. The number of data which can be handled by the above software is almost unlimited (depends upon the speed of the processor and the size of the HDU). Various works done in this context also aim to simplify the ergonomic of the software as well as the printed or screen representations of the networks or clouds of points more or less related.

A special notice must be done concerning the patents because they are the best link between the world of research and the world of the enterprises. In this area several efforts should be done. One of the best example of work develop in this direction is the MatheoPatent software which use free patent databases (US and World patent Database through the European Patent Office). This software integrates almost all the functionalities necessary to follow rapidly one patent or a family of patents, to regroup patents through APA (Automatic Patent Analysis), to search on drawings (most interesting for subjects related to engineering), to comment, export, update your search etc...For those which are interested in that field (in our opinion fundamental because of the move to a Research Economy driven) it is possible to download a free version of Matheo-Patent ${ }^{29}$.

\section{C - Extracting the right information from full text data}

Full text data is a text which cannot be analyzed by the classical means of bibliometrics. For instance abstracts of one pages, press agency wires, patent full text, web pages, full text scientific papers, newspapers data, etc...

In fact, if you index those texts, it is noticeable that using the classical way to search those data using boolean operators, string searches, etc... will give a lot of noise on one hand and on the other hand you can miss valuable data if you do not use the right terms. The use of the rank command in certain hosts allowed to expand the list of terms which can be used for the information retrieval, but even with successive iterations the results were not correct. This is very understandable since synonyms, etc... cannot represent exactly the full thinking of the expert. This is why a large number of researches have been and still are done in this field. The

\footnotetext{
${ }^{29}$ Download from http://www.matheo $\square$ patent.com (the full version is available at a cost of $600 €$ per year. The number of searches and download patent is unlimited.
} 
goal is to represent through "cartridges" for the Temis ${ }^{30}$ company for example the feeling of one or more experts. These cartridges used dictionaries, synonyms, linguistic approach, words describing the concepts necessary to the experts. Once a cartridge has been developed it is applied to the full text and this will select the texts or the parts of the texts which match the need of the experts. In this condition the search is not made any more through classical research query and language. This is a more powerful mean to retrieve information, but to establish cartridges in various languages and areas of research is expensive. Nevertheless, because of the multi-formats of the information it is clear that these retrieval systems will be used more and more widely.

The problem is more complex when languages like Chinese, Japanese ... must be analyzed. We saw in the above chapter the increasing importance of the Chinese language. The used of cartridges is more difficult to apply and people will used euristic representation of the thoughts of the experts. The MEVA system developed by the CESD and the University of Marne la Vallée is a good example of what can be done in that direction.

\section{The MEVA ${ }^{31}$ system: $^{32}$}

According to the thought of Niklas Luhmann ${ }^{33}$ any system is permanently distinguishing itself from its environment. The environment is considered by the system as a chaos. So the system is constantly seeking to reduce the complexity of the chaos by interpreting (understanding the meaning) the communications (only existing exchanges). In other words, the system reacts, observes itself in order to update, in its own memory, its available topics by the selection of the meaning. The environment, which is in perpetual change, has the capability to cause a reaction inside the system.

\footnotetext{
${ }^{30}$ 29What is a Skill Cartridge ${ }^{\mathrm{TM}}$ ?

A Skill Cartridge ${ }^{\mathrm{TM}}$ is a set of customizable knowledge components that defines the information to be extracted. The two major knowledge components of a Skill Cartridge are multi-lingual dictionaries that assign concepts to words and phrases, and multi-lingual extraction rules that establish relationships between defined concepts. An inference component provides the functionality to further interpret and normalize the extraction output. A Skill Cartridge $^{\mathrm{TM}}$ is charged into the Insight Discoverer Extractor ${ }^{\mathrm{TM}}$ that performs the extraction. Retrieved from the World Wide Web August 222008 : http://www.temis.com/index.php?id=131\&selt=1\&lg=en ${ }^{31}$ MEVA: Mémoire Evénementielle et Virtuelle d'Actualisation ; Updated Event and Virtual Memory

${ }^{32}$ This extracted from a paper of Nadège Guenec and Henri Dou to be published in Data Science Journal (Caodata) : KNOWLEDGE BUILDING IN THE FIELDS OF STI AND GEOPOLITICS FOR COMPETITIVE INTELLIGENCE STRATEGY FOR THE CHINESE MARKET - APPLICATION IN THE FIELD OF AGRICULTURAL BIOTECHNOLOGIES IN PEOPLE REPUBLIC OF CHINA, Nadège Guénec, Christian Krumeich, Clément Paoli, Henri Dou (the paper deals with the Hybrid Wheat in China.

${ }^{33}$ Barbesino P., Salvaggio S., La sociologie de Niklas Luhmann, Numéro spécial de la Revue Recherches Sociologiques, vol.2, 3-4, 1998
} 
However, regarding the Limagrain Group's (this example is taken from a paper dealing with this group in the field of hybrid seeds) interrogations about Chinese market, they are all about determining which are the social actors who will affect the evolution of the system. The observed system here is the Chinese social system in which the problems of Limagrain Group fit. This social system will be indicated hereafter by initials CSS for "Communicating Social System",34, the characteristic of a social system being the communication. It will not only be necessary to distinguish the various components of the CSS but it will also be necessary to release their relations and to determine which component will have the most favourable position to operate changes inside the system.

By the MEVA method ${ }^{35}$ the watcher will first draw out the minimal system in which the expert is located. The watcher must have a interpretative approach of the context and for that, he might put himself in situation and know his interlocutor's system, the recipient of final information. The social group to which the expert belongs has to be deciphered to capture the modalities of its environment. The border of the CSS is traced from the inside of the system itself. That is to say that the CSS defined itself by defining what it is. It thus dissociates itself from its environment which he feels as a "notmarked space" according to the expression of George Spencer-Brown ${ }^{36}$. It is the first level of observation, carried out by the expert himself. The observation is a selection by the expert of what brings up to date and potentiates a part of reality ${ }^{37}$. The watch profile, built on the basis of the expert's implicit knowledge is in fact one of the forms of the CSS. By contextualizing the knowledge, it delimits the borders of the request and potentiates the other forms.

However, only a second order observer is able to reveal the distinctions made by the system, or only him is able to perceive the two halves of the form produced by the first operation of observation: the space marked by the expert and not-marked space. The MEVA watcher is located at this second level of observation. The predictive capacities will rise out of the actualization of the expert's knowledge organized within the watch profile.

Example extract of MEVA core language

; plants (graminaceous --> monocotyledones)

\footnotetext{
${ }^{34}$ Ricoeur P., La mémoire, l'histoire, l'oubli, Ed. du Seuil, 2000

${ }^{35}$ Paoli-Scarbonchi E, L'analyse mémorielle et statistique pour la création de Banques d'Information Elaborée (BIE). Application au travers d'une plateforme de veille dans le domaine de la médecine régénératrice, thèse de doctorat Université de Marne-La-Vallée, novembre 2006

${ }^{36}$ Wikipedia, 2008, George Spencer-Brown, Bibliography, retrieved from the World Wide Web August 18, 2008 : http://en.wikipedia.org/wiki/G._Spencer-Brown

${ }^{37}$ Vygotski L., Pensée et langage, La Dispute, 1997
} 
(lex graminaceous pla)

$(\square \square \square)(\square \square \square \square \square)(\square \square \square)$

Graminaceous has rhizome $(\square \square \square \square)$

Graminaceous fourragere $(\square \square \square \square)$

(lex corolla pla/monocotyl)

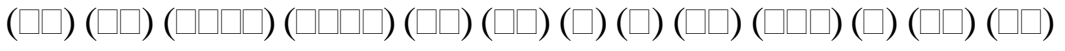

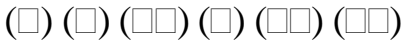

(syn* corolla corolla pedicel pedicel $(\square \square)$ stalk peduncle $(\square)$

perianth perianth ( $\square \square$ ) pericarp pericarp $(\square \square)$ chalice calix ( $\square$ )

petal petal $(\square \square)$ petiole $(\square \square)$ )

(lex cotyledon $(\square \square)$ pla/monocotyl)

(lex monocotyledone pla/monocotyl)

(syn monocotyledone angiosperme $\square \square \square \square$ (plant has seed $\square \square \square \square$ )

(vascular plant $\square \square \square \square \square$ ) (plant has flower $\square \square \square \square \square$ ) spermatophyte

(system racinaire $\square \square, \square \square, \square \square$ ) (system caulinaire $\square$ )

monocotyledonae monocotyle monocot)

(lex (principal root) pla/monocotyl)

(lex (swivelling root) pla/monocotyl)

(lex (secondary root) pla/monocotyl)

(lex (side root) pla/monocotyl)

(lex pollen $\square \square \mathrm{pla} /$ monocotyl/pollen)

; (syn pollen pollination)

$\square \square, \square \square$

(lex dicotelydone pla/dicotel)

(syn dicotelydone dicotyledonae dicots

\section{D - The creation of actionable knowledge}


It is very important to think to create an actionable knowledge from the competencies and knowledge present in various data available though the literature, exhibitions, etc... It is important also to understand that knowledge is not found. This is not because you build a large database that you will be knowledgeable. Knowledge must be created and this is the process to create knowledge which is the key of the success in Strategic Technology Watch and Competitive Intelligence. The process of creating knowledge ${ }^{38}$ is close from the cycle of intelligence which can be represented as follow:

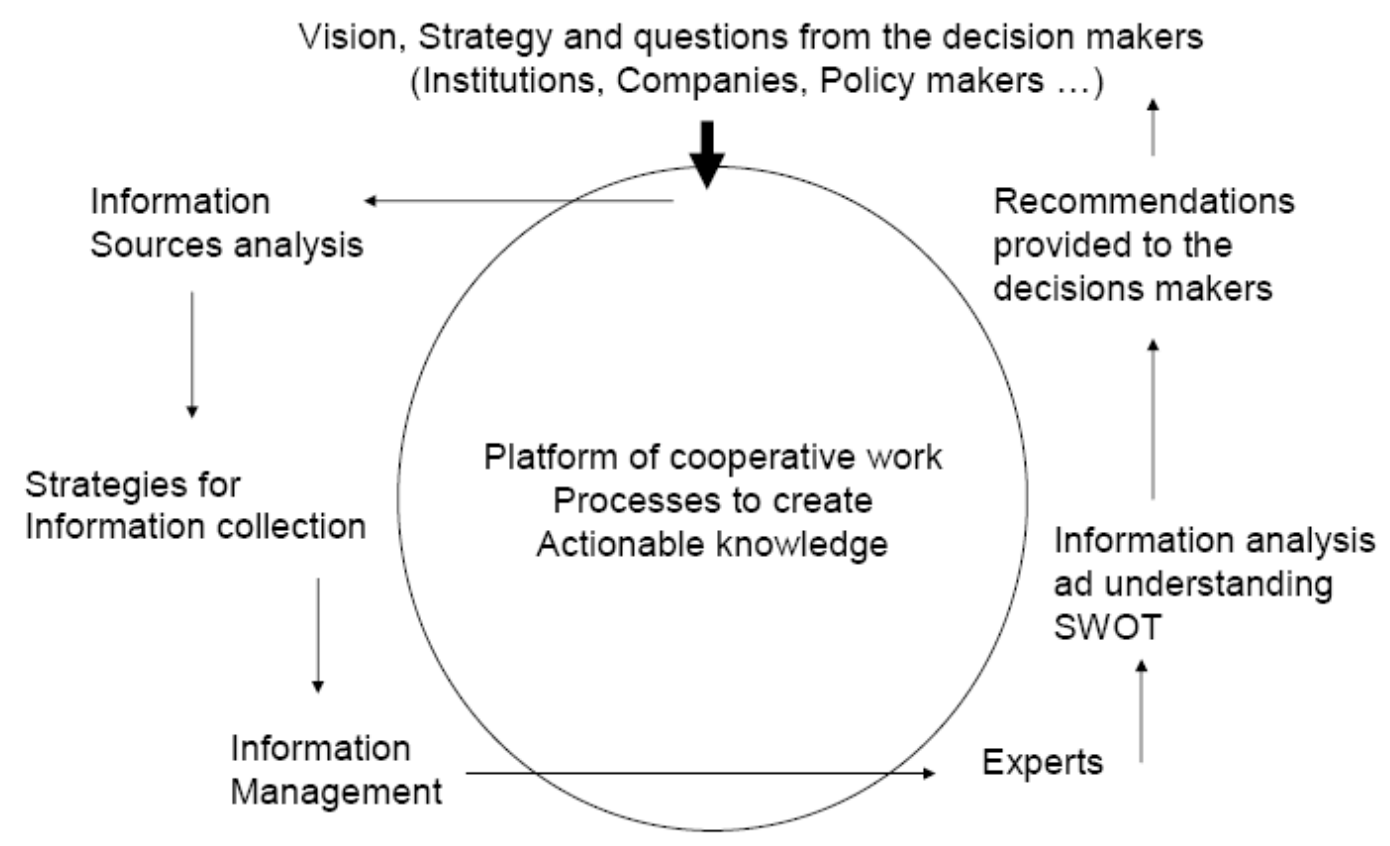

Creating knowledge is a mixture of human skill and workflow technology

Figure 4 - Competitive Intelligence cycle

The knowledge is created when the cycle : questions coming from the decision makers, information retrieval, impact of these information on the strategy of the company (through the questions asked by the decision makers) and recommendations issued by the experts. Many authors present this cycle as a mixture of human knowledge ${ }^{39}$ and workflow technology. This

\footnotetext{
${ }^{38}$ Dou Henri and Dou Jean Marie Jr, Information Science for Decision Making, ISDM Information Science for Decision Making, $\mathrm{n}^{\circ} 17$ June 2004 article $\mathrm{n}^{\circ} 174$ http://isdm.univ-tln.fr/articles/num_archives.htm

${ }^{39}$ Organizaçoes intelligentes, Editor Embrapa 2008, Roberto de Camargo Penteado Filho
} 
means that researches in this area can be developed in two different domains: social sciences with the process ${ }^{40}$ of decision and informatics with the development of platform to create knowledge. We will see the importance of a platform of collaborative treatment in the development of a Competitive Intelligence Unit in the following paragraphs.

\section{E - The WEB 2}

The development of the Internet and the increasing amount of information help to develop new aspects of the Internet output. This is called most often the WEB 2. To give various examples of Web2 outputs we can cite the RSS fluxes, the citation from Google scholar, the dynamic clustering.

Web $2.0^{41}$ is a term describing changing trends in the use of World Wide Web technology and web design that aims to enhance creativity, information sharing, and, most notably, collaboration among users. These concepts have led to the development and evolution of web-based communities and hosted services, such as social-networking sites, video sharing sites, wikis, blogs, and folksonomies. The term became notable after the first O'Reilly Media Web 2.0 conference in 2004.[2] [3] Although the term suggests a new version of the World Wide Web, it does not refer to an update to any technical specifications, but to changes in the ways software developers and end-users utilize the Web. According to Tim O'Reilly: Web 2.0 is the business revolution in the computer industry caused by the move to the internet as platform, and an attempt to understand the rules for success on that new platform.

$\mathrm{RSS}^{42}$ is a family of Web feed formats used to publish frequently updated content such as blog entries, news headlines, and podcasts in a standardized format.[2] An RSS document (which is called a "feed," "web feed,"[3] or "channel") contains either a summary of content from an associated web site or the full text. RSS makes it possible for people to keep up with web sites in an automated manner that can be piped into special programs or filtered displays.[3]

The benefit of RSS is the aggregation of content from multiple web sources in one place. RSS content can be read using software called an "RSS reader," "feed reader," or an "aggregator," which can be web-based or desktop-based. A standardized XML file format

\footnotetext{
${ }^{40}$ L'Intelligence Economique, Lavoisier Hermes, 2008 Chapter 10 La dimension prospective de l'outil « homme» pp. 255-281

${ }^{41}$ Retrieved from the World Wide Web August 20th 2008 : http://en. wikipedia.org/wiki/Web_2.0

${ }^{42}$ Retrieved from the World Wide Web August 29th 2008 : http://en.wikipedia.org/wiki/RSS_(file_format) 
allows the information to be published once and viewed by many different programs. The user subscribes to a feed by entering the feed's link into the reader or by clicking an RSS icon in a browser that initiates the subscription process. The RSS reader checks the user's subscribed feeds regularly for new content, downloads any updates that it finds, and provides a user interface to monitor and read the feeds.

Citations -Publish or Perish ${ }^{43}$ Most of the people are accustomed to the citation index of the SCI. But, other indexes can be developed such as the citation index from Google Scholar data. The software to make such a citation index is available through the Harzing Company and it is free. This company emphasizes the fact that social interaction if very important in the development of knowledge 44 .

Example, citation from one author (Henri Dou or Dou Henri)

\begin{tabular}{|c|c|c|c|c|c|c|c|c|c|c|}
\hline \multicolumn{11}{|c|}{ 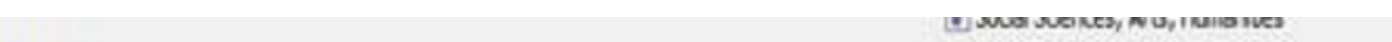 } \\
\hline \multicolumn{11}{|l|}{ Results } \\
\hline $\begin{array}{l}\text { Papers: } \\
\text { Otators: } \\
\text { Years: } \\
\text { Otes/year: }\end{array}$ & $\begin{array}{l}55 \\
13 ! \\
39 \\
3.35\end{array}$ & $\begin{array}{l}\text { Otes } \\
\text { Oter } \\
\text { Pape } \\
\text { Auth }\end{array}$ & $\begin{array}{l}\text { S/poper: } \\
\text { fasthoe: } \\
\text { ers/auther: } \\
\text { ershoces: }\end{array}$ & $\begin{array}{l}2.38 \\
64.15 \\
25.37 \\
2.71\end{array}$ & $\begin{array}{l}\text { h-ndex: } \\
\text { grndex: } \\
\text { heindex: } \\
\text { hindex: } \\
\text { hilnorm: }\end{array}$ & $\begin{array}{l}6 \\
9 \\
3 \\
240 \\
5\end{array}$ & $\begin{array}{l}\text { AWCR: } \\
\text { AW index: } \\
\text { AWCRp: }\end{array}$ & & & - \\
\hline Otes & Per yes & $\operatorname{Ran} k$ & Authors. & & Tite & & & Yes & Publcabon & $p=$ \\
\hline (V) 29 & 1.38 & $t$ & JKste, M & cons, & Changes in & the che & scal strucere of... & 1983 & Fuet & E \\
\hline W] 9 & 0.64 & 2 & $\mathrm{HDou}, \mathrm{JDo}$ & & Wrtud rese: & srchun & erses and reses... & 1995 & Techology Andyses a Strat... & r \\
\hline$\sqrt{6} s$ & 1.00 & J & Y bertacdi & $\mathrm{i}, \mathrm{HDON}$ & The Tentor & a Com & ebtrie Inteliger... & 2001 & Astes du Coloque VSST 2001 & $a$ \\
\hline ( 7 & 0,44 & 4 & Quoris & M,PHA, & Bolometrix & andy: & of potent dxam." & 1993 & Restarch Evaluston & \\
\hline [1] 7 & 0.54 & It: & HDOU & & Velle bectine & ologas & & 1996 & Tedrigues de Ingtrieur. L'... & c) \\
\hline W. 6 & 0,43 & 14 & Hoov & & Velie Tecth & ologqu & et Compditovt & 1995 & Dunod, Pris & \\
\hline V 5 & 0.29 & 15 & F XXxoetA & $\mathrm{HOO}$... & - De linfort & abent & omerisire Ola... & 1992 & Lo vele tectnologove: int... & \\
\hline (1) 5 & 0.59 & 5 & GMEe, 10 & en, HDou & Polyoydic A & romase & Iydrecabers in... & 1982 & Internatenal Journal of Envi... & r \\
\hline (5) 5 & 0.33 & 16 & HDOU & & Motroer la & crollfer & ben de finformat.. & 1994 & Tectnolopes tenternatonsles & \\
\hline V. 4 & 0.40 & 6 & HOON, $2 \mathrm{Ne}$ & $000 x$ & Irnovston & morag: & ient tednologr... & 1999 & titemational Journd of tifo... & $E$ \\
\hline (v) 4 & 0.25 & 7 & HOess & & Tedrubiogy & Wotch & nd Compebtre $n$ & 1993 & Edxaton fox Informaton & e \\
\hline [1] 3 & 0.00 & 8 & & & Bendmaks & $9 R B D$ & nd compuries t... & & & \\
\hline$\sqrt{3} 3$ & 0.50 & 10 & HDou, SO: & tandang & Conpetbive & intelo & nce, technologr... & 2003 & & * \\
\hline (1) 3 & 0.39 & 23 & $\mathrm{HOON}, \mathrm{QM}$ & costro & tensognen & ent de & nteligence comn... & 2001 & Humanisme et Entreqrice, NaS & \\
\hline (1) 3 & 0.38 & 22 & GMCoehs, & HDou & La soceted d & le la cel & vissance et les.... & $200 t$ & Marstle: Urwerste Ax Mar... & q \\
\hline [V] 3 & 0.43 & 24 & HDOU & & Poseer de lo & ręré: & ntabon du prés... & 2002 & Humaneme et entregrise(Pa... & c \\
\hline (V) 3 & 0.14 & 9 & HOON & & Tesding QC & blocet: & Anslygs and $M_{\text {... }}$ & 1980 & Educston for informaton & e \\
\hline (V) 2 & 0,00 & 13 & & & Itrost of $\mathrm{s}$ & moe: & e ntelogense on... & & & \\
\hline V] 2 & 0.08 & $5 t$ & J Koster, M & fulana,... & Analyse Qu & enta: & par Spectrosce... & 1995 & Internabonal Journal of Eni,.. & re. \\
\hline
\end{tabular}

Clustering engines There are many clustering engines available on the Internet at no cost. We will give here an example of the result obtain from the clustering engine

\footnotetext{
${ }^{43}$ Retrieved from the World Wide Web August 20th 2008 : http://www.harzing.com/resources.htm\#/pop.htm

${ }^{44}$ On becoming a high impact journal in international business and management, Ane Wil Harzing, Euriopean Journal of information Management, 2/2, 200
} 
SearchCrystal ${ }^{45} 44$. A search is made with an author name, a concepts, etc... various search engines are used to retrieve the data and all the link between the data are present in a network.

The following figure show the result of the cluster done with the name Henri Dou

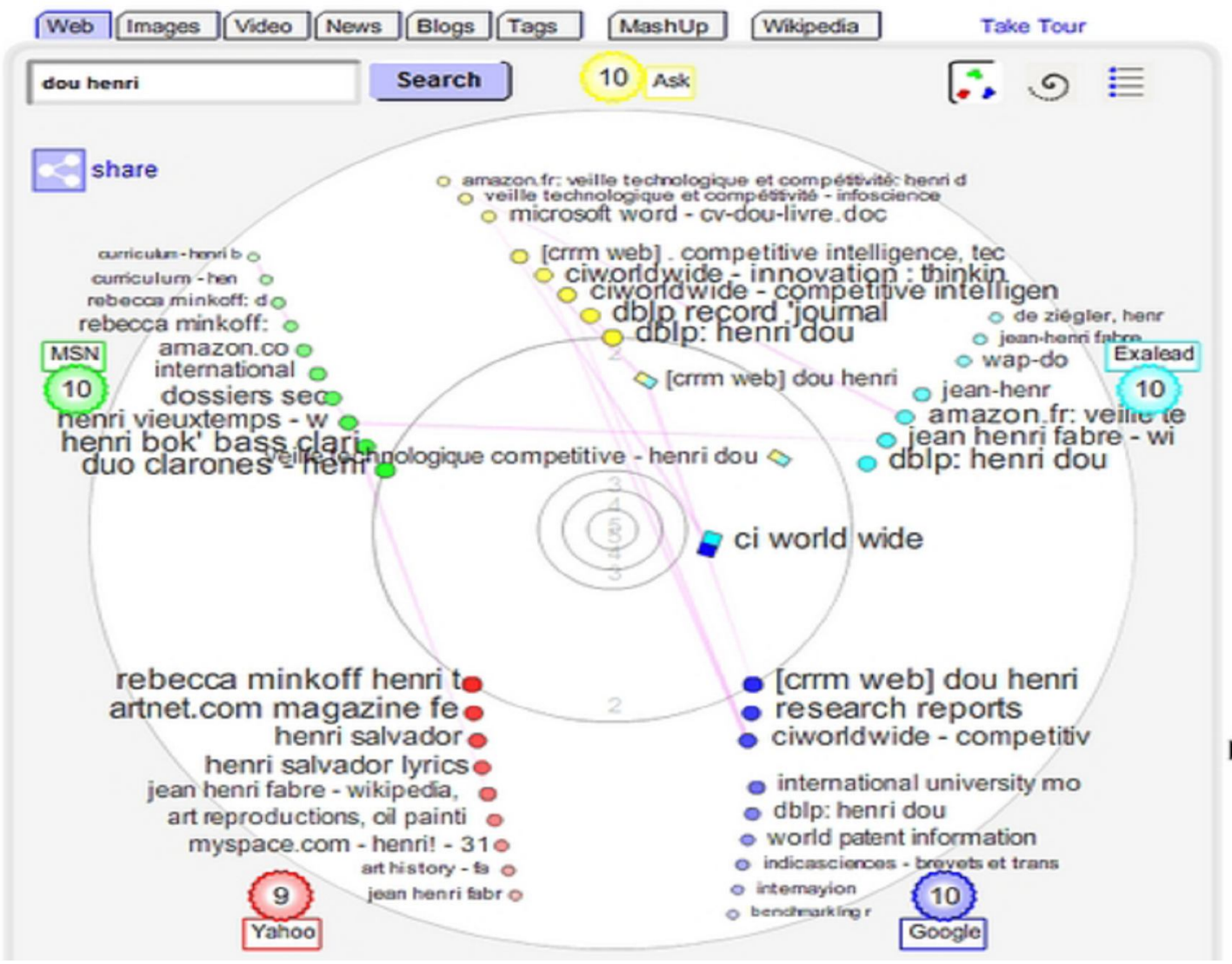

Figure 5 - Result from a search cluster engine

Note that the cluster can be done using Web, video, pictures, blogs, etc... Dynamic clusters can also be introduced into your web applications. ${ }^{46}$

\section{VI - Examples of Competitive Intelligence and Competitive Technical Intelligence}

In this last paragraph we will develop briefly some examples of the use of CTI to choose the best orientations and to increase innovation and research results.

\section{A - The case of a research laboratory}

\footnotetext{
${ }^{45}$ Retrieved from the World Wide Web August 20th 2008: http://www.searchcrystal.com/home.html

${ }^{46}$ Consult CIWORLDWIDE expert clusters http://www.ciworldwide.org
} 
In Marseille, the laboratory of Complex Organic Chemistry ${ }^{47}$ develops its own CTI Unit. This Unit which is not considered by the direction of the CNRS from which this laboratory depends as a wasted time! (this shows how it is difficult to innovate and to change the frame of mind of people). But this Unit enable the laboratory to expand its activities from a core knowledge (the ageing of complex chemical compounds) to cosmetics (through the directive REACH of the European community), to biodiesels since the combustion in diesel engine will be shortly speaking related to ageing and to agribusiness specially in looking to the quality of various oil such as olive oil, etc... The CTI Unit acts as a catalyst pushing people to analyse more and more information before developing a research, to spot industrial partners (from proceedings and patents) and to increase in value the global competencies of the researchers. The CTI Unit had also part of its activity centred on the uses of the various analytical techniques. In the same time, the fundamental research developed by the laboratory increases and the laboratory was requested to participate to various regional and national poles of competitiveness. This laboratory developed a Unit based on Matheo-Patent ${ }^{48}$ to analyze the patents through APA (Automatic Patent Analysis) and to Matheo-Analyzer ${ }^{49}$ to analyze the structured data from the literature. In hte same time a network of partners provides also informal information to the direction of the Unit.

Lesson to learn: CTI not only increases the partnership of the laboratory with industry and regional institutions (through the poles of competitiveness), but also the CTI increases dramatically the fundamental research production. CTI should be associated with all educational and research institutions.

\section{B - The case of one SME}

A regional SME (South of France) specialized in the development of agricultural machines and tools uses widely the patent information not only to protect its inventions but also to observe the development of the new applications and competitors in the field of its activities. This is the CEO of the company with one of his assistant which take care of this task, using professional literature (when available) and searching permanently the patent databases. This SME has now more than 65 patents and also was able to detect several

\footnotetext{
${ }^{47}$ UMR6171 CNRS. Dr Jacky Kister - University Paul Cézanne, Centre Scientifique de St Jérôme, 13397 Marseille cedex 20 France email jacky.kister@voila.fr

${ }^{48}$ For more information on free trial visit http://www.matheo-patent.com

${ }^{49}$ For more information on this software visit http://www.matheo $\square$ anlyzer.com 
imitations of its own products leading to discussion and creation of various exchanges and partnerships.

Lesson to learn: SME have no time to take fundamental research results and to integrate them in their production development. The patents provide a unique information which links the science and technology $y^{50}$. In this condition patents are not only a system of protection, but they are also a way to know what is going on in terms close from the industrial thinking. Very often searching patents in the field of development of the SME is a good way to promote innovation and to open for the decision makers a window on the science technology, competitors and fundamental research.

\section{C - The case of a virtual cluster}

In France the pole of competitiveness are located as well as the stakeholders in the same region. (your feet in the region and your eyes turned to the world !). But in some cases this is different. For instance in Thailand ${ }^{51} 50$, in the field of coconuts, an extensive use of Matheo-Patent to analyze the patent production in that field is done by a national CTI Unit. All the results according the critical factor of success (which are here a little different since linked to the strategic orientation of the country in that field and also to the technical knowledge of the national firms of the cluster) are extracted from the patent databases and disseminate among the virtual cluster. The following figure 6 , give an example of the data extracted and disseminated:

\footnotetext{
${ }^{50}$ Hearing $97 \square$ Patents in Europe $\square$ Usage and dissemination of Patents as a tool to improve SME's strategies Dou H. $\square$ Hearing 1997, p.66 $\square 68 \square$ Proceedings on the future patent information policy of the EPO Technology Forecasting in Competitive Intelligence: The use of Patent Analysis Karadsah Suryadi, Agus Salim Ridwan, Henri Dou, Andrian Purnama isdm n ³, 1999 http://isdm.univ $\square$ tln.fr/articles/num_archives.ht ${ }^{51}$ เอกสารประกอบการเสวนาทางวิชาการ เรื $\square$ อง การแปรรูปและการใช้ประโยชน์จากมะพร้าว 2 มิถุนายน 2548 http://www.toryod.com/patentanalysis.php and http://www.ip.kku.ac.th/idea/1.map.pdf
} 


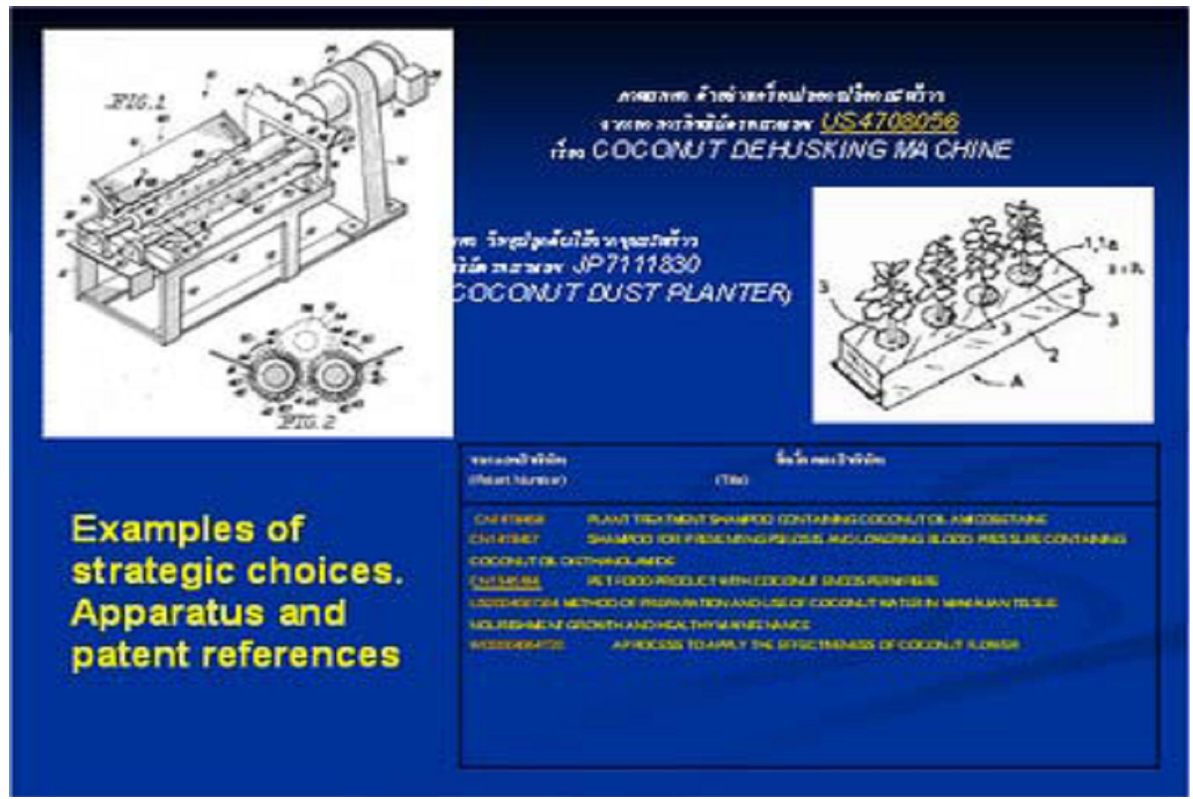

Figure 6 - Extraction of strategic information from patents

Lesson to learn: a CTI Unit can be used as a virtual provider of strategic information. The use of various types of platforms to disseminate and comments the information is the fastest way to increase the innovation potential of the stakeholders.

\section{D - Strengthening the human network}

This can be done at a national level. Let us see the Lattes database developed by the Brazil. This database if done under the framework of the $\mathrm{CNPq}$ (this is the national institution which takes care of the research development in Brazil). In Brazil all Brazilian researchers or other which benefit from the State of contracts, grants and which are engaged in cooperative works with Brazilian researchers must have their full vitae plus papers published and links with laboratories of various institutions in the database Lattes. This database is available and more than six hundred thousand people have their vitae registered. The implementation of the database is done by the researchers themselves, the incentive is very simple if you do not have relevant data in the Lattes database, you are not eligible for any grants or help from the CNPq. The database and the computer infrastructure are maintained by the CNPq. The database can be reached upon the following Internet address: http://lattes.cnpq.br/.

Lessons to learn: in Competitive Intelligence as well as in CTI, the commitment of the state is important since the state can provide facilities that companies and regional governments do not have. CTI like Competitive Intelligence is not only a particular matter, but this is also a national issue. 
The following figure 7, shows the main screen of the Lattes database.

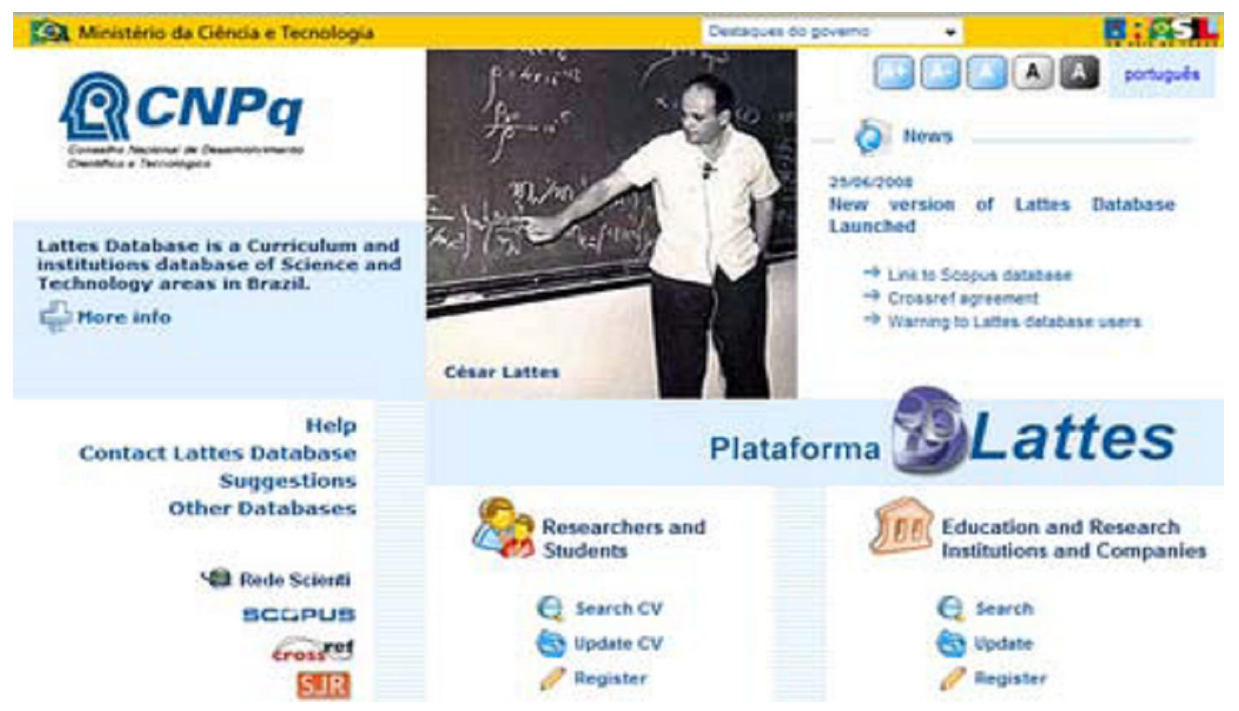

Figure 7: the main screen of the Lattes database

\section{C - The case of a large company, worldwide leader}

We will present here some results obtained from the SEB group ${ }^{52}$. This company is a world leader in household appliances and anti-adhesive culinary pans and tools. The company has a large number of marks and also its development was mainly linked to external partnerships or acquisitions of specialized companies in that field. Then the SEB group is present in almost all continents and must maintain its competitive advantages through innovation, since the competition in that field is very hard and that the companies present in that field are very concentrated. The CTI system of the SEB group is quite close of what we presented in the above paragraph, the organization put a strong emphasis on the education of the corresponding members. The CFS are divided not only on a product base but also according the various technologies which help the SEB products to be very innovative with no equivalent on the market. The CTI system is evaluated about twice a year and top decision akers of the group participate to the evaluation. It is clear that this system functions with a mixture of human skill and workflow technology. The corresponding members must really be part of the system and they must receive a clear letter of mission (they have their usual work into the company plus the task of analyzing the information related to the CFS that they must survey.

\footnotetext{
52 The SEB CTI system was partially developed by a student of the DEA Technology Watch. See the following reference: Capital issue 198 March 2008, Seb Champion de l'innovation
} 
In the case of the SEB group, the corresponding members can search by themselves the commercial technical and scientific databases available for instance via Dialog. They also access the internal information system of the group, providing information about home specialists and data relevant to the SEB products and technologies development. The CTI system which started in the year 1999 is now extended to all the group. The goal being to have a large portfolio of patents on one hand either by cooperation or by self development and then to develop an innovative line of products.

Most of the time the CTI outputs and successes are not divulgated since the CTI deals with very strategic aspects of the development of the company. But in the case of the SEB group we can refer to a magazine article which presented the SEB way to maintain its position vis à vis of the Asian competitors. The following figures illustrate some of the successes of the SEB group, Successes due for a large part to the CTI output, analysis and survey.

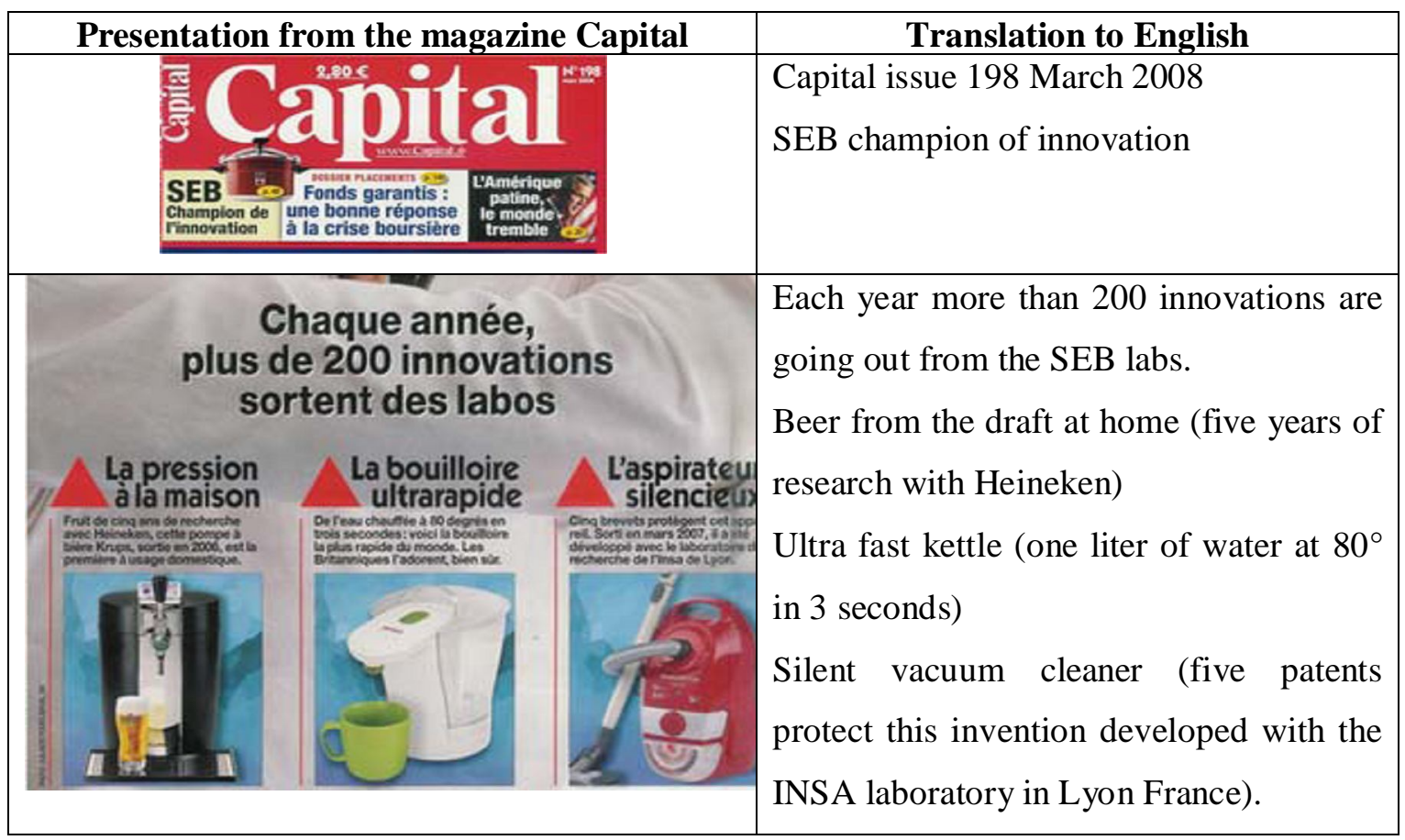




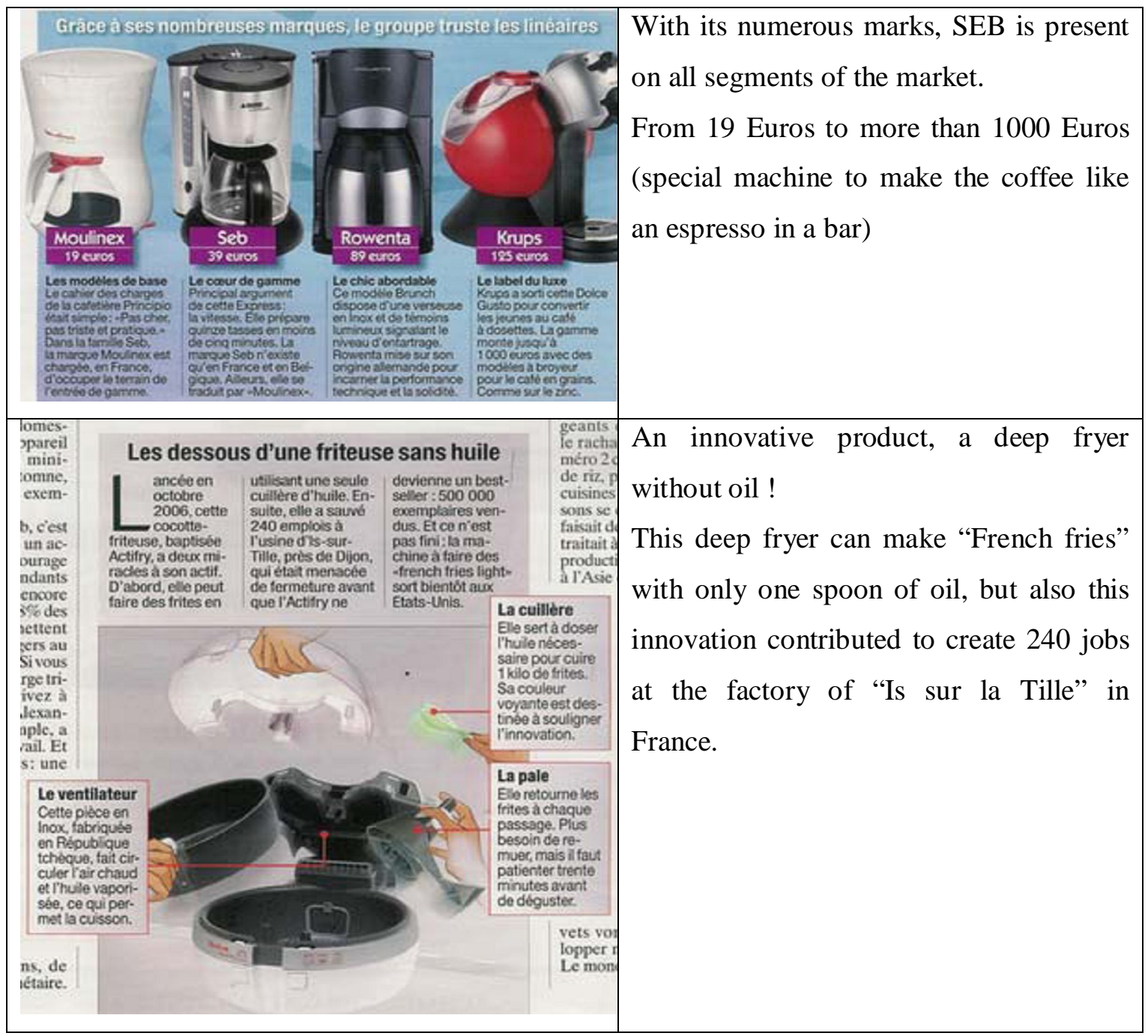

\section{Conclusion}

The development of research in the field of Technology Watch, Competitive Intelligence, Competitive Technical Intelligence and Knowledge Management is very often a matter of "good sense". Improving the organization seems one of the key of the success as well as developing human network and strong organization of the experts and corresponding members of the network. It is clear, that after will be coming some more precise topics such as bibliometrics, APA, platform to create knowledge and to disseminate data, etc... Another point which is important is to develop some platform which will allow the researchers to access foreign databases (such as Chine and Japanese) and to perform on this databases various analysis. Another important point is to develop strategies to access the informal information (primary information source) this is fundamental because it is the complement of 
the formal one. Another point linked to the organization is the way that the company, the region, the nation will develop its strategic technologies. On each one the knowledge which is developed should be carefully manage to avoid the loss of competitiveness and share with selected companies.

If all the above areas are important, it is also fundamental to take care of the internal information, the information created in the company in the region in the nation. It is obvious that tracking its own knowledge will take a large part in the global success. But, it is also important to use all the tools available to benchmarks its facilities and knowledge with the foreign ones. This should be done without concession. In this are the use of the SWOT analysis is one of the best simple and performing tool.

And the last point is to be persevering, many times you will not be successful, many times the decision makers will not take care of your recommendations. But, persevering is the key of success, do not discourage yourself and keep going on.

Acknowledgement: I will like to thank very much the UNB and specially the department of "post graduação" for their king invitation to participate to the symposium of Information Science organized by UNB in Brasilia. 